\title{
Why public health matters today
}

\section{Pourquoi la santé publique aujourd'hui?}

\author{
Trevor Hancock ${ }^{1} \cdot$ Lindsay McLaren ${ }^{2}$
}

Received: 7 April 2019 / Accepted: 14 April 2019 / Published online: 28 May 2019

(C) The Author(s), under exclusive licence to The Canadian Public Health Association 2019

This special section on why public health matters today has its origins in the CJPH Editorial Board's concern about "the continued erosion of public health in Canada" (Hancock 2017a), noting the publication of several editorials and commentaries in recent years that had characterized public health as weakened (Guyon et al. 2017), "under siege" (Potvin 2014) and "under attack" (Guyon and Perreault 2016).

It was to help counter this erosion that the Editorial Board made its call for submissions "that explore, and provide evidence for, the value of public health to Canada today". The extent to which the articles published here do that we leave to your judgement, although we comment on the submissions and the underlying issues they raise in an accompanying editorial (McLaren and Hancock 2019). In this editorial, we seek to both answer the question of WHY public health matters and explore what the public health field (professionals and organizations) needs to do to make the benefits of public health more apparent.

So why does public health matter? In a nutshell, public health matters because health matters. "A nation's health is a nation's wealth", as proclaimed in the masthead of The Sanitarian, a Victorian-era public health journal, is an idea that is echoed by Canada's first Chief Public Health Officer, Dr. David ButlerJones, who called the health of the public "the foundation of prosperity" (Cabaj et al. 2019). In its editorial, the CJPH Board stated its belief that "Public health matters for society, and the benefits of prevention have been clearly demonstrated: a healthy population is a social good" (Hancock 2017a). This is why health matters to the public and to governments.

Trevor Hancock

thancock@uvic.ca

1 University of Victoria, Victoria, BC, Canada

2 University of Calgary, Calgary, $\mathrm{AB}$, Canada
The importance of health itself is apparent in the frequency with which health is a matter of public interest on the internet and is a frequent topic in the media. It is apparent in the fact that there is a major UN organization - the World Health Organizationthat is dedicated to improving health. And it is apparent in the high value Canadians place upon the health care system and the high proportion of both GDP (expected to be $11.3 \%$ in 2018) and provincial expenditures (around 37\% in 2016) that are committed to that system (Canadian Institute for Health Information 2018).

In modern times, our knowledge of population health has led us to understand-perhaps "re-discover" would be a better word - that most of the determinants of health lie beyond health care (Health and Welfare Canada 1974; No authors 1985; Evans et al. 1994; McGovern et al. 2014). Thus, it can and should be argued that maintaining and protecting the health, well-being and quality of life of the population is - or should be - the main function of government. Again, hardly a new notion: the Roman orator, writer and senator Cicero wrote almost 2000 years ago "Salus populi suprema lex - Let the good of the people be the supreme law" (Cicero, in De Legibus, approx 44 BC).

This is one reason why public health matters; because one of public health's strengths over the years has been that to a significant extent its work has been oriented outside the health care system, addressing the major determinants of health in the community and in society as a whole. That has been particularly the case at the local level, where public health practitioners (physicians, nurses, inspectors and others) work with community organizations, municipal governments, school boards, local businesses and many others to create the conditions for good health.

At national and provincial levels, the public health community has taken on industries that harm health (tobacco, alcohol, foods and beverages, chemicals, autos and, more recently, fossil fuels, to name but a few) and sought to change government policies on environmental, social and economic issues so as to protect and promote health. And it has led to calls for a 
"whole of government" approach to health with the development of healthy public policies and the use of health impact assessments (Senate of Canada, Sub-Committee on Population Health 2009). All of these areas of work indicate why advocacy is a duty for public health professionals (Hancock 2015).

However, public health also matters to the health care system. As the Editorial Board argued, investment in public health activities can make an important contribution to the financial and social sustainability of the health care system. Specifically, the Board agreed with the view that there is "No quality health care without strong public health" (Rose 1985) because public health contributes to the health care system achieving its Triple Aim of improved population health, improved patient experience of care and reduced per capita cost of health care (Hancock 2017a). Improved quality of care comes first of all from not having the disease, injury or disability to begin with, so not needing the care (Rose 1985); this is the best outcome we can wish for (Hancock 2017b).

What makes public health's contribution to the health of the population distinct and valuable is that it is the only part of the health care system dedicated solely to protecting and promoting the health of the population and preventing illness and injury. This is not to say that other health care professionals do not do prevention - indeed they do, especially primary care providers - but that is only one of their functions, and not the major one, not where they spend most or all of their time. Moreover, public health is the only part of the system focused on the health of entire communities and the population as a whole, rather than on an individualistic approach, which dominates elsewhere in the system.

In addition, public health can make a large contribution to the financial sustainability of the health care system by reducing the burden of disease and injury-including reducing the excess burden of disease attributable to inequalities in healthand thus the demands on and the cost of the health care system. Indeed, for any fiscally prudent health system manager, reducing the burden of disease should be their first priority; nothing is cheaper than not having to provide the care in the first place.

So public health matters for the sake of the health of the population, for the well-being and prosperity of Canada and for the sake of its health care system. Investing in public health is one of the most cost-effective interventions any government could make to achieve these aims. This is why the failure to invest in public health and prevention is such an enigma, especially given that Canada's Ministers of Health recognized the importance of health promotion and disease and injury prevention in their 2010 Declaration "Creating a Healthier Canada: Making Prevention a Priority" (Ministers of Health and Health Promotion/Healthy Living 2010).

The Ministers recognized that "the promotion of health and the prevention of disease, disability and injury are a priority and necessary to the sustainability of the health system" and that "a better balance between prevention and treatment must be achieved". They also noted that "Prevention needs to be the first step in management" of chronic disease and disabilities (since preventing additional health problems is very important in these situations) and that "Prevention is a hallmark of a quality health system". Sadly, however, their actions have generally failed to match their rhetoric.

In fact, the weakness of the commitment to prevention across Canada led Canada's provincial and territorial Chief Medical Officers of Health in 2017 to take the highly unusual step of going public with their concerns, a step that speaks volumes about the level of their concern. They noted "a greater focus on preventive and public health measures will be required", that "reviving a national prevention agenda is key to sustainability of health care in Canada", and went so far as to "implore health ministers to reaffirm commitment to the principles outlined in the declaration" (Strang et al. 2017) (emphasis added).

While there are many reasons why the erosion in public health has occurred, we believe that part of the reason is that we in public health have not done a good enough job of promoting its value for Canadians and for the health care system within which-like it or not - public health is now largely situated across Canada.

A few years ago, in accepting the Frank A. Calderone Prize in Public Health from the Mailman School of Public Health at Columbia University, the noted American health activist Dr. Jack Geiger observed that while the public health community has done much good work on the determinants of population health, "too much of that has constituted talking to ourselves rather than talking to the public". (Indeed, this special section can be seen as another example of us talking to ourselves.) This has to change, he stated: "We have to talk to the public, give legislative testimony at every level, flood the blogosphere, write letters to the editor, raise our voices" on the radio and in op-eds (A message for public health from Jack Geiger 2014). In short, we have to make the case for public health to the public whom we serve.

That said, if we want to build a strong, well-resourced and effective system of population and public health services, advocacy from public health professionals will not be enough and may be seen simply as self-interest. It is unfortunate that there is currently no public health "movement" along the lines of the environmental, women's, gay rights, civil rights or labour movements, or even the holistic health and wellness movement.

Now, it is not easy for health professionals to create a social movement - in the more than 30 years since the 1986 Ottawa Charter, health promotion has largely failed to do so. But if public health matters - and obviously we believe it does - it has to be seen to be important by the public and the civil society organizations, including other health professions, that are our natural allies across the entire range of population and public health challenges we face as a society. Thus, our challenge is not simply to make the case ourselves but to start 
talking to and working with the public and with our potential allies, creating a public health movement that in turn can make the case to governments.

Where to begin? Well, as a national framework for a renewed public health sector and a renewed national and provincial commitment to prevention, the 2010 Ministers' Declaration is still a good starting point. We need to be active as a profession and mobilize our partners in support of the Declaration, insisting that the Ministers and their governments put their money where their mouths are - not for our sakes as public health professionals, but for the sake of the health of the population and the sustainability of the health care system.

Perhaps we and our civil society and general public allies should seek a commitment from Canada's First Ministers and the leaders of all the opposition and other parties at every election that they will accept and act upon the Ministers' Declaration and make prevention a priority. It would be a good place to start.

\section{Éditorial}

Notre rubrique spéciale, «Pourquoi la santé publique aujourd'hui? », trouve son origine dans les craintes du comité éditorial de la RCSP face à « l'érosion constante des capacités en santé publique au Canada (Hancock 2017a)», étant donné la publication de plusieurs éditoriaux et commentaires ces dernières années selon lesquels la santé publique est affaiblie (Guyon et al. 2017), « en état de siège (Potvin 2014) » et « en butte à des attaques (Guyon et Perreault 2016) ».

C'est pour freiner cette érosion que le comité éditorial a lancé un appel d'articles qui explorent « la valeur de la santé publique au Canada aujourd'hui et [qui présentent] des preuves à l'appui ». Ce sera à vous de voir si les articles publiés ici remplissent cette mission, mais nous commentons ces articles et les questions sous-jacentes qu'ils soulèvent dans un éditorial connexe (McLaren et Hancock 2019). Dans le présent éditorial, nous tentons à la fois de répondre à la question de savoir POURQUOI la santé publique importe et d'explorer ce que le milieu de la santé publique (les professionnels et les organismes) doit faire pour rendre les avantages de la santé publique plus apparents.

Pourquoi donc la santé publique importe-t-elle? En gros, parce que la santé importe. « La santé fait la richesse de la nation » proclamait le générique d'une revue de santé publique de l'époque victorienne, The Sanitarian; l'idée a été reprise par le premier administrateur en chef de la santé publique du Canada, $\mathrm{D}^{\mathrm{r}}$ David Butler-Jones, qui qualifiait la santé du public de « fondement de la prospérité (Cabaj et al. 2019) ». Dans son éditorial, le comité de la RCSP a énoncé la conviction que « La santé publique importe pour la société, et les avantages de la prévention sont clairement démontrés : une population en bonne santé est un bien social (Hancock 2017a)». Voilà pourquoi la santé importe pour le public et pour l'État.

L'importance de la santé se voit à la fréquence à laquelle elle intéresse la population dans Internet et elle est abordée dans les médias. Elle se voit au fait qu'une institution de l'ONU - l'Organisation mondiale de la santé - est vouée à son amélioration. Et se voit à la grande valeur accordée par la population canadienne au système de santé et à la forte proportion du PIB (11,3\% en 2018 selon les prévisions) et des dépenses provinciales (environ $37 \%$ en 2016) qui est consacrée à ce système (Canadian Institute for Health Information 2018).

À l'époque contemporaine, nos connaissances en santé des populations nous ont fait comprendre peut-être que « redécouvrir » serait un meilleur terme - que la plupart des déterminants de la santé se trouvent au-delà des soins de santé (Health and Welfare Canada 1974; No authors 1985; Evans et al. 1994; McGovern et al. 2014). Nous pouvons et nous devons donc faire valoir que la préservation et la protection de la santé, du bien-être et de la qualité de vie de la population constituent - ou devraient constituer - la principale fonction de l'État. Cela non plus n'a rien de nouveau : l'orateur, écrivain et sénateur romain Cicéron écrivait il y a plus de 2000 ans « Salus populi suprema lex - Le salut du peuple est la loi suprême » (Cicéron, De Legibus, vers 44 av. J.-C.).

C'est aussi l'une des raisons de l'importance de la santé publique : l'une de ses forces, au fil des ans, est que dans une large mesure, son travail s'oriente vers l'extérieur du système de santé et aborde les grands déterminants de la santé dans la population et dans la société en général. C'est particulièrement vrai au niveau local, où les praticiens de la santé publique (médecins, infirmières, inspecteurs et autres) travaillent avec les organismes de proximité, les administrations municipales, les conseils ou commissions scolaires, les entreprises locales et beaucoup d'autres à créer les conditions d'une bonne santé.

À l'échelle nationale et provinciale, la communauté de la santé publique a défié des industries dont les activités menacent la santé (le tabac, l'alcool, les aliments et boissons, les produits chimiques, l'automobile et, plus près de nous, les combustibles fossiles, pour n'en nommer que quelques-unes) et demandé la modification de politiques gouvernementales sur des questions environnementales, sociales et économiques pour protéger et promouvoir la santé. Cela a donné lieu à des appels à une démarche « pangouvernementale » de la santé avec l'élaboration de «politiques pour la santé » et l'utilisation d'évaluations d'impact sur la santé (Senate of Canada, SubCommittee on Population Health 2009). Tous ces chantiers montrent pourquoi l'action sociale est un devoir pour les professionnels de la santé publique (Hancock 2015).

La santé publique importe aussi pour le système de santé. Comme l'a soutenu le comité éditorial, investir dans les activités de santé publique peut apporter une importante 
contribution à la durabilité financière et sociale du système de santé. En particulier, le comité s'est dit d'accord avec l'opinion selon laquelle « il est impossible d'offrir des soins de santé de qualité en l'absence d'un secteur de la santé publique vigoureux (Rose 1985) », car la santé publique contribue à la réalisation du triple objectif du système de santé : une meilleure santé des populations et une meilleure expérience des services de santé à un meilleur coût par habitant (Hancock 2017a). L'amélioration de la qualité des soins commence par l'absence de maladies, de blessures ou d'invalidités, ce qui élimine la nécessité des soins (Rose 1985); c'est la meilleure issue à espérer (Hancock 2017b).

Ce qui fait la singularité et la valeur de la contribution de la santé publique à la santé des populations, c'est qu'elle constitue le seul rouage du système de santé consacré exclusivement à la protection et à la promotion de la santé des populations et à la prévention des maladies et des blessures. Cela ne veut pas dire que les autres professionnels de la santé ne font pas de prévention - il n'y a aucun doute qu'ils en font, surtout les prestataires de soins primaires - mais ce n'est que l'une de leurs fonctions, et non la principale, et ce n'est pas celle à laquelle ils consacrent la plupart ou la totalité de leur temps. De plus, la santé publique est le seul rouage du système axé sur la santé de toutes les collectivités et de la population dans son ensemble, plutôt que d'adopter la démarche individualiste qui domine ailleurs dans le système.

En outre, la santé publique peut apporter une grande contribution à la durabilité financière du système de santé en réduisant le fardeau des maladies et des blessures - y compris la charge de morbidité excédentaire imputable aux inégalités en santé - et donc les pressions exercées sur le système de santé et les coûts afférents. En fait, pour tout gestionnaire prudent des budgets du système de santé, réduire la charge de morbidité devrait être la première priorité; rien n'est plus abordable que de ne pas avoir à offrir de soins pour commencer.

Donc, la santé publique importe pour la santé des populations, pour le bien-être et la prospérité du Canada et pour le système de santé du pays. Les investissements en santé publique sont parmi les interventions les plus rentables de n'importe quel gouvernement pour atteindre ces objectifs. C'est pourquoi le non-investissement dans la santé publique et la prévention est une énigme, surtout que les ministres de la Santé du Canada ont reconnu en 2010 l'importance de la promotion de la santé et de la prévention des maladies et des blessures dans leur déclaration intitulée « Pour un Canada plus sain : faire de la prévention une priorité (Ministers of Health and Health Promotion/Healthy Living 2010)».

Les ministres ont reconnu que « la promotion de la santé et la prévention des maladies, des incapacités et des blessures sont prioritaires et nécessaires à la viabilité du système de santé » et que « nous devons atteindre un meilleur équilibre entre la prévention et le traitement». Ils ont aussi noté que « la prévention doit être la première étape de la gestion » des maladies chroniques et des invalidités (car il est très important de prévenir les problèmes de santé supplémentaires dans ces circonstances) et que « la prévention est une caractéristique distinctive d'un réseau de la santé de qualité ». Malheureusement, leurs discours ne se sont généralement pas traduits en gestes concrets.

En fait, le trop faible engagement en faveur de la prévention au Canada a poussé les directeurs de la santé et les médecins hygiénistes en chef des provinces et des territoires à prendre en 2017 la mesure inédite de dévoiler publiquement leurs motifs de préoccupation, mesure qui en dit long sur leur inquiétude. Ils ont noté qu'il convient d'insister davantage sur les mesures de prévention et de santé publique, qu'il est essentiel à la durabilité des soins de santé au Canada de relancer un plan d'action national sur la prévention, et sont allés jusqu'à implorer les ministres de la Santé de réaffirmer leur engagement envers les principes directeurs de la déclaration de 2010 (Strang et al. 2017).

Les raisons de l'érosion de la santé publique sont nombreuses, mais nous croyons que nous et nos collègues portons une part de responsabilité en n'ayant pas suffisamment promu la valeur de la santé publique pour la population canadienne et pour le système de santé dans lequel - que cela nous plaise ou non - s'insère dans une large mesure la santé publique au Canada.

Il y a quelques années, en acceptant le prix Frank A. Calderone décerné par l'École de santé publique Mailman de l'Université Columbia, l'éminent militant pour la santé $\mathrm{D}^{\mathrm{r}}$ Jack Geiger a fait observer que la communauté de la santé publique avait fait du bon travail sur les déterminants de la santé des populations, mais qu' " une trop grande partie de ce travail a consisté à parler entre nous au lieu de nous adresser au public ». (À vrai dire, la présente rubrique spéciale pourrait être considérée comme un autre exemple de conversation entre nous.) Il faut que cela change, a-t-il énoncé. " Nous devons parler au public, témoigner devant les législateurs à tous les paliers, inonder la blogosphère, écrire au courrier des lecteurs, nous exprimer haut et fort " à la radio et dans des articles d'opinion (A message for public health from Jack Geiger 2014). Bref, nous devons présenter les arguments en faveur de la santé publique à la population que nous servons.

Cela dit, si nous voulons bâtir un système solide, efficace et bien pourvu pour offrir des services de santé publique et des populations, le militantisme des professionnels de la santé publique ne suffira pas - il pourrait même être perçu comme une simple défense de leurs intérêts personnels. Il y a lieu de déplorer l'absence actuelle d'un « mouvement » pour la santé publique inspiré des mouvements pour les droits civils et de l'environnement, des femmes et des gais, du mouvement ouvrier, ou même du mouvement pour la santé et le mieux-être holistiques.

Admettons qu'il n'est pas facile pour les professionnels de la santé de créer un mouvement social - depuis plus de 30 ans 
que la Charte d'Ottawa a été signée en 1986, la promotion de la santé a en grande mesure échoué à cet égard. Mais si la santé publique importe - et de toute évidence nous croyons que c'est le cas - son importance doit être perçue par le public et par les organisations de la société civile, dont les autres professions de la santé, qui sont nos alliés naturels face au vaste éventail des problèmes de santé publique et des populations auquel nous sommes confrontés en tant que société. Le défi n'est donc pas simplement d'en établir la preuve nous-mêmes, mais de commencer à parler et à travailler avec le public et nos alliés potentiels, créant ainsi un mouvement pour la santé publique qui à son tour pourra en plaider la cause devant l'État.

Par où commencer? Eh bien, pour encadrer au palier national le renouvellement du secteur de la santé publique et les engagements nationaux et provinciaux à l'égard de la prévention, la déclaration ministérielle de 2010 est encore un bon point de départ. Toute notre profession doit activement convaincre nos partenaires d'appuyer cette déclaration, en insistant pour que les ministres et leurs gouvernements se donnent les moyens de leurs promesses - non pas dans l'intérêt des professionnels de la santé publique, mais dans celui de la santé de la population et de la durabilité du système de santé.

Peut-être faudrait-il, avec la société civile et nos alliés dans le grand public, demander aux premiers ministres et aux chefs des partis d'opposition et des autres partis du Canada, à chaque élection, de s'engager à accepter la déclaration ministérielle, à y donner suite et à faire de la prévention une priorité. Ce serait un excellent point de départ.

Author contribution Trevor Hancock is an Associate Editor of the Canadian Journal of Public Health and Co-Editor, Special Section on Why Public Health Matters Today. Lindsay McLaren is a Senior Editor of the Canadian Journal of Public Health and Co-Editor, Special Section on Why Public Health Matters Today.

\section{References/Notes bibliographiques}

A message for public health from Jack Geiger. Public Health Now Nov. 10, 2014. https://www.mailman.columbia.edu/public-healthnow/news/message-public-health-jack-geiger. Accessed 28 March 2019.

Cabaj, J. L., Musto, R., \& Ghali, W. A. (2019). Public health: who, what, and why? Canadian Journal of Public Health, 110(3). https://doi. org/10.17269/s41997-019-00207-2.

Canadian Institute for Health Information. (2018). National Health Expenditure Trends, 1975 to 2018. Ottawa: CIHI https://www.cihi. $\mathrm{ca} /$ sites/default/files/document/nhex-trends-narrative-report-2018en-web.pdf. Accessed 30 Mar 2019.

Evans, R., Barer, M., \& Marmor, T. (Eds.). (1994). Why are some people healthy and others not? The determinants of the health of populations. New York: Aldine de Gruyter.

Guyon, A., \& Perreault, R. (2016). Public health systems under attack in Canada: evidence on public health system performance challenges arbitrary reform. Canadian Journal of Public Health, 107(3), e326e329. https://doi.org/10.17269/cjph.107.5273.

Guyon, A., Hancock, T., Kirk, M., MacDonald, M., Neudorf, C., Sutcliffe, P., et al. (2017). The weakening of public health: a threat to population health and health care system sustainability [Editorial]. Canadian Journal of Public Health, 108(1), e1-e6. https://doi.org/ 10.17269/cjph.108.6143.

Hancock, T. (2015). Advocacy: it's not a dirty word, it's a duty [Editorial]. Canadian Journal of Public Health, 106(3), e86-e88.

Hancock, T. (2017a). Erosion of public health capacity should be a matter of concern for all Canadians [Editorial]. Canadian Journal of Public Health, 108(5-6), e458-e460.

Hancock, T. (2017b). No quality health care without strong public health. CMAJ, 189, E1435. https://doi.org/10.1503/cmaj.171287.

Health and Welfare Canada. (1974). A new perspective on the health of Canadians (The Lalonde Report). Ottawa: Health \& Welfare Canada.

McGovern, L., Miller, G., \& Hughes-Cromwick, P. (2014). Health Policy Brief: the relative contribution of multiple determinants to health outcomes. Health Affairs. https://doi.org/10.1377/hpb20140821. 404487.

McLaren, L., \& Hancock, T. (2019). Public health matters - but we need to make the case [Editorial]. Canadian Journal of Public Health, 110(3). https://doi.org/10.17269/s41997-019-00218-z.

Ministers of Health and Health Promotion/Healthy Living. (2010). Creating a healthier Canada: Making prevention a priority - a declaration on prevention and promotion from Canada's Ministers of Health and Health Promotion/Healthy Living. Ottawa: PHAC Available at: http://www.phac-aspc.gc.ca/hp-ps/hl-mvs/declaration/ pdf/dpp-eng.pdf. Accessed September 22, 2017.

No authors (1985). Beyond health care: proceedings of a working conference on healthy public policy. Canadian Journal of Public Health, 76 (Suppl. 1), 1-104.

Potvin, L. (2014). Canadian public health under siege [Editorial]. Canadian Journal of Public Health, 105(6), e401-e403. https:// doi.org/10.17269/cjph.105.4960.

Rose, G. (1985). The strategy of preventive medicine (p. 4). Oxford: Oxford University Press.

Senate of Canada, Sub-Committee on Population Health. (2009). A healthy, productive canada: a determinant of health approach. Ottawa: The Senate of Canada.

Strang, R., Kendall, P., Corriveau, A., \& on behalf of the provincial/ territorial chief medical officers of health with the exception of Quebec. (2017). Reviving a national prevention agenda is key to sustainability of health care in Canada. CMAJ, 189, E1250E1251. https://doi.org/10.1503/cmaj.170694.

Publisher's note Springer Nature remains neutral with regard to jurisdictional claims in published maps and institutional affiliations. 